\title{
The American College of Preventive Medicine Position Statement on Hepatitis
}

\section{Virus Infection}

Robert D. Allison, MD, MPH, ${ }^{1}$ Steven A. Hale, MD,${ }^{2}$ Bart J. Harvey, MD, PhD, MSc, MEd, ${ }^{3}$

Toni Hudson, MSPH, ${ }^{4}$ Catherine Livingston, MD, MPH, ${ }^{5}$ Kevin M. Sherin, MD, MPH, MBA, ${ }^{6}$

Kelechi A. Uduhiri, MD, MPH, MS, ${ }^{7}$ David W. Niebuhr, MD, MPH, MSc ${ }^{8}$ and the American

College of Preventive Medicine Prevention Practice Committee

From the ${ }^{1}$ Johns Hopkins Bloomberg School of Public Health, Baltimore, Maryland; ${ }^{2}$ University of Central Florida College of Medicine, Florida Department of Health in Orange County, Orlando, Florida; ${ }^{3}$ Dalla Lana School of Public Health, University of Toronto, Toronto, Canada;

${ }^{4}$ Florida Department of Health in Orange County, Orlando, Florida; ${ }^{5}$ Oregon Health and Science University, Portland, Oregon; ${ }^{6}$ University of Central Florida College of Medicine, Florida State University College of Medicine, Orlando, Florida; ${ }^{7}$ Providence Hospital Department of Family Medicine, Washington, District of Columbia; and ${ }^{8}$ Uniformed Services University of Health Sciences, Bethesda, Maryland

Address correspondence to: David W. Niebuhr, MD, MPH, MSc, Uniformed Services University of the Health Sciences, Department of Preventive Medicine and Biostatistics, 4301 Jones Bridge Road, Bethesda MD 20814-4712. E-mail: david.niebuhr@usuhs.edu. 
The American College of Preventive Medicine Prevention Practice Committee contributes to policy guidelines and recommendations on preventive health topics for clinicians and public health decision makers. After review of the currently available evidence, the College is providing a consensus-based set of recommendations designed to increase screening for and prevention of hepatitis $\mathrm{C}$ virus infection, increase linkage to care, improve access to treatment, and to encourage development of hepatitis C virus-related quality measures. 


\section{Introduction}

An estimated 185 million people have been infected with hepatitis C virus (HCV) globally ${ }^{1}$ and chronic HVC infection is a major cause of liver cirrhosis and hepatocellular carcinoma. ${ }^{2}$ Approximately 1,778 acute HCV infections were reported in the U.S. in 2012, an increase of 75\% from $2010 .{ }^{3}$ After adjusting for asymptomatic infections and under-reporting, CDC estimates 21,870 new HCV infections occurred in $2012 .{ }^{3}$ Of the 3.6 million individuals in the U.S. with HCV antibody, approximately 2.7 million are thought to be chronically infected, though this likely represents a significant underestimation. ${ }^{4-6}$ Between $75 \%$ and $85 \%$ of those infected with $\mathrm{HCV}$ are expected to progress to chronic disease, with varying rates in selected subgroups. ${ }^{7-10}$ Disease burden is also disproportionate in people who are uninsured or have publically funded insurance. ${ }^{11}$ Further, an estimated $22 \%$ of the chronic HCV cases occur in African Americans even though African Americans represent only $12 \%$ of the U.S. population. ${ }^{11}$ HCV-related mortality is highest among individuals aged 55-64 years (25.2 deaths/100,000 population in 2013), American Indians/Alaska Natives (12.2 deaths/100,000 population), and men (approximately 2.6 times the rate for women). ${ }^{12}$ New outbreaks of $\mathrm{HCV}$ infection have been observed among young adult injection drug users in predominantly suburban and rural areas and have been linked to opioid abuse. ${ }^{13-16}$

Infection with $\mathrm{HCV}$ is the leading cause of advanced liver disease and the leading indication for liver transplant, and was the underlying or contributing cause of death in 19,368 people in the U.S. in $2013 .{ }^{17} \mathrm{~A}$ major challenge is that most infected individuals are asymptomatic or unaware of their illness. 


\section{Screening for Hepatitis C Virus Infection}

“Baby boomers," defined as people born between 1945 and 1965, are estimated to account for $75 \%$ of individuals infected with $\mathrm{HCV}$ and are on average five times more likely to be infected than any other age group in the overall U.S. population. ${ }^{18}$ In 2012 and 2013, CDC and the U.S. Preventive Services Task Force (USPSTF) addressed the high prevalence of HCV infection in the baby boomer population by recommending a one-time screening for the virus in people born between 1945 and 1965 regardless of their history of risk factors for infection. ${ }^{14,17,19}$ In addition to age-cohort based screening, CDC and USPSTF recommended screening in people at high risk for $\mathrm{HCV}$ infection, including those with HIV infection. ${ }^{20}$ Risk factors for HCV infection include injection or intranasal drug use, receiving a blood transfusion before 1992, long-term hemodialysis, being born to an $\mathrm{HCV}$-infected mother, incarceration, receiving an unregulated tattoo, and other percutaneous exposures. In addition, the following groups may be considered high risk on a case by case basis and warrant HCV screening: recipients of transplanted tissue (e.g., corneal, musculoskeletal, skin, ova, and sperm), people with a history of non-injected illegal drug use, individuals with a history of tattooing or body piercing, people with a history of multiple sex partners or sexually transmitted diseases, and long-term steady sex partners of HCV-positive individuals.

\section{Special Populations}

\section{Young Prescription Opioid Abusers Who Transition to IV Drug Use}

Analysis of data from the general U.S. population has shown an HCV prevalence higher in men than women, in non-Hispanic blacks than non-Hispanic whites, and among people born from 1945 to $1965 .^{21}$ However, a new and growing epidemic of HCV infection has been recognized 
recently among adolescent and young adult people who inject drugs living primarily in suburban and rural communities. ${ }^{13-16}$ Further, these young adults often initiated drug use with oral prescription opioids (without a doctor's prescription) before transitioning to IV drug use. ${ }^{13,22}$ In fact, this new epidemic of HCV infection overlaps temporally and geographically with the ongoing epidemic of prescription drug abuse in the U.S. ${ }^{23}$

\section{HIV/Hepatitis C Virus Coinfection Among Men Who Have Sex With Men}

Coinfection with HIV/HCV is a global public health problem in men who have sex with men (MSM), where the prevalence of coinfection surpassed 90\% prior to effective HIV/AIDS outreach programs and interventions and more recently has been estimated to be $16 \%$ in the U.S. ${ }^{24-26}$ A 2012 systematic review found that HIV-positive MSM had 4.1 times higher risk of acquiring HCV infection than HIV-negative MSM. ${ }^{25}$ Since 2000, evidence has accumulated for permucosal transmission of HCV among HIV-infected MSM in Europe, Australia, the U.S., and Asia. ${ }^{27}$ The Multicenter AIDS Cohort Study prospectively followed 5,310 HCV antibody (antiHCV)-negative MSM from 1984 to 2011 for anti-HCV seroconversion. ${ }^{28} \mathrm{HIV}$ infection and unprotected receptive anal intercourse with more than one male partner were independent significant risk factors for $\mathrm{HCV}$ seroconversion. ${ }^{28}$ The $\mathrm{HCV}$ incidence rate was inversely proportional up to a CD4 T-cell count of 500 cells $/ \mathrm{mm}^{3}$ and there was no association with highly active antiretroviral therapy. ${ }^{28}$

Specific sexual practices such as unprotected anal intercourse, manual insertion of fingers into the rectum ("fisting"), and other traumatic sexual practices may potentiate HCV transmission because trauma to the mucosal lining frequently results in bleeding. ${ }^{29,30}$ Certain drugs such as crystal methamphetamine are nasally or rectally used by some subpopulations of HIV-positive 
MSMs. These drugs may cause behavioral disinhibition and increased pain threshold, thus enhancing risk-taking behavior involving traumatic sexual practices that last longer and are more intense with potential for significant mucosal inflammation and bleeding. ${ }^{31}$ A $2007-2008$ crosssectional survey among MSM attending a large sexually transmitted infection clinic found that HIV infection, IV drug use, fisting, and gamma hydroxybutyrate use were significantly associated with HCV infection among MSM. ${ }^{32}$

\section{Linkage to Care}

Recent advances in oral therapies for HCV treatment have presented an opportunity to link individuals to effective care, reduce community viral load, and also reduce transmission rates. With only $32 \%-38 \%$ of all $\mathrm{HCV}$-infected people receiving follow up hepatitis care, and only $5 \%-6 \%$ successfully treated, effective linkage to care and treatment is critical to improve outcomes. ${ }^{33}$

Improved utilization of primary care systems, including Federally Qualified Health Centers and patient-centered medical homes, and utilization of inpatient settings and emergency rooms could increase screening rates, counseling to prevent infection, transmission and progression, access to care, and treatment opportunities. ${ }^{34,35}$ New resources for guidelines such as www.hcvguidelines.org are available to inform both primary care and specialist physicians. ${ }^{36}$

Barriers to care for patients with $\mathrm{HCV}$ infection include treatment contraindications, competing treatment priorities, loss to follow-up, treatment duration, adverse effects, lack of access to treatment, high price, and lack of practitioner expertise. These barriers can be addressed through 
multiple approaches. Population-based strategies include the use of a case management model such as with HIV, directly observed therapy, co-location of primary care with drug treatment programs and other services such as needle exchange programs, assurance of coverage for HCVinfected people through the Patient Protection and Affordable Care Act, and optimal use of Pharmaceutical Patient Assistance Programs. ${ }^{36}$ New Mexico is trying to improve access in rural communities through use of telemedicine with Project ECHO at the University of New Mexico to increase provider training and support for treatment. ${ }^{37}$

Once linked to care, behavioral counseling and education are critical components for improved HCV disease outcomes. Counseling should include avoidance of alcohol and other hepatotoxins; behavior modifications to reduce blood transfer such as sharing toothbrushes, dental or shaving equipment, and illicit drug use and needle sharing; donation of blood or organs; and the use of barrier precautions to reduce the risk of sexual transmission by patients with HIV infection or those with multiple sex partners.

\section{Access to Treatment}

The most recent direct and indirect cost estimates of HCV infection for the U.S. were \$694$\$ 1,660$ million and $\$ 1,780$ million per year, respectively. ${ }^{38,39}$ The cost of care for patients who develop cirrhosis from HCV infection is driven by complications such as decompensated cirrhosis, variceal hemorrhage, refractory ascites, liver transplant, and hepatocellular carcinoma. ${ }^{40}$ The reduction in HCV-related complications with treatment and cure has the potential to markedly decrease these costs. 
There has been considerable concern raised about the price of direct-acting antiviral agents (DAAs) approved for use in the last 2 years. However, the actual prices paid, specifically the prices paid after negotiations between pharmaceutical companies and pharmacy benefit managers, private insurance companies, or Medicaid plans, are rarely known. This is because negotiated prices are confidential business contracts, with the exception of mandated rebates given to federal government agencies. ${ }^{41}$ It is well recognized that the high prices of DAAs and subsequent restrictions on DAA reimbursement have reduced patient access to treatment. ${ }^{42-44}$ For example, 31 of $42(75 \%)$ states with known Medicaid reimbursement criteria for sofosbuvir limit access to this drug to patients with advanced fibrosis, 37 (88\%) states have requirements related to substance abuse, and 14 (33\%) states have prescriber type restrictions. ${ }^{42} \mathrm{~A}$ disproportionate number of people with chronic HCV infection in the U.S. live on incomes near the poverty level and therefore are disproportionately impacted by HCV treatment restrictions. ${ }^{42}$ These restrictions, and thus limitations to access, are not consistent with current recommendations from professional medical organizations. ${ }^{36}$

Until recently, $\mathrm{HCV}$ treatments consisted of a combination of a DAA with peginterferon and ribavirin. ${ }^{45,46} \mathrm{~A}$ new class of DAA has significantly improved the treatment of $\mathrm{HCV}$ infection and includes sofosbuvir, ledipasvir, paritaprevir, ombitasvir, dasabuvir, daclatasvir, simeprevir, elbasvir, and grazoprevir. ${ }^{47}$ Newer, all-oral, interferon-free DAAs have minimal side effects, cure rates $>90 \%$ for all genotypes except in select patient populations, and evidence has amassed in the past year that they are cost effective in the U.S. ${ }^{48-53}$ The societal willingness-to-pay threshold is typically considered to range from about $\$ 50,000$ to $\$ 100,000$ per quality-adjusted life year. ${ }^{44}$ Compared with the interferon-based old standard of care, the incremental cost- 
effectiveness ratios per quality-adjusted life year ranged from $\$ 12,825$ to $<\$ 100,000$ with higher incremental cost-effectiveness ratios in people with less severe fibrosis. ${ }^{48-53}$ However, significant improvement in long-term survival with treatment at earlier stages of fibrosis has been observed in recent studies, strongly supporting treatment of people with less severe fibrosis ${ }^{54,55}$ It is important to note that no cost-effectiveness analysis to date has included the added potential benefit of treatment to reduce HCV transmission.

Guided by the cumulative evidence, professional medical organizations have recently updated their guidelines in August 2015 and now recommend treatment for all patients with chronic HCV infection, except those with short life expectancies owing to comorbid conditions ${ }^{36}$ (Table 1). Despite robust evidence and recommendations supporting treatment, there is a current access to care crisis. It is important to note that the high prices and coverage restrictions causing this crisis are not the result of immutable conditions, but the consequence of decisions made by pharmaceutical companies, pharmacy benefit managers, and private and public insurers. Efforts of all stakeholders should be coordinated to better ensure that policy and decision making around treatment are equitable, evidence-based, and maximize the public health benefit to society.

\section{Quality Measures}

The development and use of HCV quality measures have the potential to improve HCV screening and linkage to care. There are three main performance measure sets:

1. ORYX $^{\circledR}$ measures used by The Joint Commission as part of the hospital accreditation process;

2. the Healthcare Effectiveness Data and Information Set consisting of 80 measures across 
five domains of outpatient care and currently used by $>90 \%$ of healthcare plans to measure performance; and

3. the Physician Quality Reporting System, a required pay-for-performance program for eligible professionals who treat Medicare patients. ${ }^{56-58}$

The use of quality measures has been associated with improvements in clinical performance in non-hepatitis related areas. For example, national programs that publicly report quality data have shown significant improvements in process measures and lower mortality rates for heart attacks, heart failure, and pneumonia. ${ }^{59,60}$ Also, although few peer-reviewed published studies exist, some found that every $10 \%$ increase in adherence to a quality measure was associated with a $10 \%$ improvement in outcomes. ${ }^{61}$

Currently, there are no ORYX ${ }^{\circledR}$ or Healthcare Effectiveness Data and Information Set measures related to HCV. In the Physician Quality Reporting System, there are eight measures related to HCV. None are related to HCV screening recommendations or to linkage to care. ${ }^{62}$ This represents a missed opportunity for setting benchmarks and improving HCV care.

In February 2014, the Office of HIV/AIDS and Infectious Disease Policy, Office of the Assistant Secretary for Health, DHHS published the "Action Plan for the Prevention, Care, and Treatment of Viral Hepatitis," updated for 2014-2016. ${ }^{63}$ This plan presented 155 specific actions that 14 agencies or offices from across four federal departments will implement including seven progress measures. The plan includes specific goals to increase the proportion of individuals who are aware of their $\mathrm{HCV}$ infection and to reduce the number of new HCV infections. Priority areas identified in the plan include educating providers and communities to reduce health 
disparities and improving testing, care, and treatment to prevent liver disease and cancer. Evidence-based strategies outlined by the DHHS action plan could well be used as a starting point for development of HCV quality measures.

\section{Recommendations From Other Professional Organizations}

Recommendations on HCV screening, transfer of care, and treatment prioritization by professional organizations along with the level of evidence and date of each are presented in Table 1.

\section{Recommendations From the American College of Preventive Medicine}

The American College of Preventive Medicine (ACPM) is the medical specialty society that addresses population health. The following is a list of ACPM population-based recommendations for HCV screening, prevention, linkage to care, and access to treatment developed by a review of the current scientific literature including the evidence-based guidelines of other professional organizations. These recommendations were developed in a consensus-based manner in the ACPM Prevention Practice Committee and endorsed by the ACPM Board of Regents.

\section{Recommendations for Screening}

1. Screening for HCV infection at least once for people born between 1945 and 1965 and in certain high-risk populations to include individuals with HIV and those who use or have used IV drugs. Targeted screening of young (aged <30 years) oral opioid prescription abusers and people who use IV drugs living in rural and suburban areas should be considered. USPSTF and CDC should evaluate the expansion of screening 
recommendations to high $\mathrm{HCV}$ prevalence secondary care venues such as inpatient, emergency departments, and behavioral health settings.

2. The National Committee for Quality Assurance, The Joint Commission, and the Centers for Medicare and Medicaid Services consider the development of quality and accountability measures for HCV screening based on the age guidelines recommended by CDC and USPSTF.

\section{Recommendations for Prevention}

1. Counseling on behavior modifications to reduce blood transfer such as avoiding sharing toothbrushes and dental or shaving equipment, illicit drug use and needle sharing, improved access to evidence-based drug abuse treatment programs, continuing HCV screening prior to donation of blood or organs, and using barrier precautions to reduce the risk of sexual transmission by patients with HIV infection or those with multiple sex partners.

2. Research into the efficacy of DAA usage as pre- and post-exposure prophylaxis for HCV infection.

3. Research for development of an $\mathrm{HCV}$ vaccine.

4. Comparative effectiveness research of drug abuse treatment interventions such as pharmacotherapy and needle exchange programs.

\section{Recommendations for Linkage to Care}

1. The National Committee for Quality Assurance, The Joint Commission, and the Centers for Medicare and Medicaid Services consider the development of quality and accountability measures for linkage to HCV disease care. 
2. The DHHS Office of HIV/AIDS and Infectious Disease Policy Action Plan for the Prevention, Care, and Treatment of Viral Hepatitis should be adopted by non-federal HCV stake holders to include state and local health departments and healthcare plans.

3. Asymptomatic individuals who screen positive for current (active) infection should receive early confirmation, be provided quantitative HCV RNA and genotyping, and evaluated for treatment.

4. Behavioral counseling should be provided to decrease the risk of HCV transmission and infection. Providers should serve as patient advocates and assist with linkage to drug treatment programs.

5. Treatment decisions should be made by the patient and provider after several factors are considered, including stage of disease, $\mathrm{HCV}$ genotype, comorbidities, therapy-related adverse events, and benefits and harms of treatment.

\section{Recommendations for Access to Treatment}

1. A coordinated and multifaceted approach with all stakeholders is needed to optimize access to new direct-acting antiviral therapy for $\mathrm{HCV}$ and to ensure policy and decision making around treatment are equitable, evidence-based, and maximize the public health benefit to society. The impacts of restrictions on treatment access should be measured and publicly shared to direct decision making processes.

2. Other opportunities to improve access should be used including case management models such as with HIV, Direct Observed Therapy, use of telemedicine to enable providers to access specialty support, co-location of primary care with drug treatment programs and other services, assurance of coverage for HCV-infected people through the Patient 
Protection and Affordable Care Act, and optimal use of Pharmaceutical Patient Assistance Programs.

\section{Conclusions}

This article briefly reviewed the literature regarding the public health implications of the HCV epidemic. The burden of disease related to HCV infection is expanding. Fortunately, new treatment options are proving to be highly effective on both an individual and population basis. The ACPM policy statements presented here are consistent with recommendations from other federal agencies and professional organizations. Critical areas for development of healthcare policy, improvement of public health practices, and continued research are highlighted. Only through a coordinated and multifaceted approach with multiple stakeholders can the goal of reduced morbidity, mortality, and the associated personal and societal costs be realized. 


\section{Acknowledgments}

The authors wish to thank Joah Aliancy, MS III Florida State University College of Medicine, Andrea Lowe, MPH, CPH, ACPM and Anita Balan BA, MCHES, ACPM for their assistance in the preparation of the manuscript and Philip N. Styne MD, AGAF, Florida Hospital, Michael Muszynski, MD, and Christopher Novak, MD, MPH, Department of Health, New Mexico, for their review and suggestions that improved the quality of this paper. The views expressed herein are the authors and do not reflect the views of the authors' federal or state agencies or private institutions to include the Uniformed Services University of the Health Sciences, the Department of the Army, and the Department of Defense. The American College of Preventive Medicine Prevention Practice Committee and the American College of Preventive Medicine Board of Regents have reviewed and approved the content of this manuscript.

No financial disclosures were reported by the authors of this paper. 


\section{References}

1. Mohd Hanafiah K, Groeger J, Flaxman AD, Wiersma ST. Global epidemiology of hepatitis $\mathrm{C}$ virus infection: new estimates of age-specific antibody to $\mathrm{HCV}$ seroprevalence. Hepatology. 2013;57(4):1333-1342. http://dx.doi.org/10.1002/hep.26141.

2. El-serag HB. Hepatocellular carcinoma. $N$ Engl J Med. 2011;365(12):1118-1127. http://dx.doi.org/10.1056/NEJMra1001683.

3. Klevens RM, Liu S, Roberts H, Jiles RB, Holmberg SD. Estimating acute viral hepatitis infections from nationally reported cases. Am J Public Health. 2014;104(3):482-487. http://dx.doi.org/10.2105/AJPH.2013.301601.

4. Denniston MM, Jiles RB, Drobeniuc J, et al. Chronic hepatitis C virus infection in the United States, National Health and Nutrition Examination Survey 2003 to 2010. Ann Intern Med. 2014;160(5):293-300. http://dx.doi.org/10.7326/M13-1133.

5. Edlin BR, Eckhardt BJ, Shu MA, Holmberg SD, Swan T. Toward a more accurate estimate of the prevalence of hepatitis C in the United States. Hepatology. 2015;62(5):1353-1363. http://dx.doi.org/10.1002/hep.27978.

6. Gish RG, Cohen CA, Block JM, et al. Data supporting updating estimates of the prevalence of chronic hepatitis B and C in the United States. Hepatology. 2015;62(5):1339-1341. http://dx.doi.org/10.1002/hep.28026.

7. Allison RD, Conry-cantilena C, Koziol D, et al. A 25-year study of the clinical and histologic outcomes of hepatitis $\mathrm{C}$ virus infection and its modes of transmission in a cohort of initially asymptomatic blood donors. J Infect Dis. 2012;206(5):654-661. http://dx.doi.org/10.1093/infdis/jis410. 
8. Thomas DL, Thio CL, Martin MP, et al. Genetic variation in IL28B and spontaneous clearance of hepatitis C virus. Nature. 2009;461(7265):798-801. http://dx.doi.org/10.1038/nature08463.

9. Dyal HK, Aguilar M, Bhuket T, et al. Concurrent Obesity, Diabetes, and Steatosis Increase Risk of Advanced Fibrosis Among HCV Patients: A Systematic Review. Dig Dis Sci. 2015;60(9):2813-2824. http://dx.doi.org/10.1007/s10620-015-3760-3.

10. Konerman MA, Mehta SH, Sutcliffe CG, et al. Fibrosis progression in human immunodeficiency virus/hepatitis C virus coinfected adults: prospective analysis of 435 liver biopsy pairs. Hepatology. 2014;59(3):767-775. http://dx.doi.org/10.1002/hep.26741.

11. Stepanova M, Kanwal F, El-serag HB, Younossi ZM. Insurance status and treatment candidacy of hepatitis $\mathrm{C}$ patients: analysis of population-based data from the United States. Hepatology. 2011;53(3):737-745. http://dx.doi.org/10.1002/hep.24131.

12. Steele CB, Meléndez-Morales L, Campoluci R, DeLuca N, Dean HD. Health Disparities in HIV/AIDS, Viral Hepatitis, Sexually Transmitted Diseases, and Tuberculosis: Issues, Burden, and Response, A Retrospective Review, 2000-2004. Atlanta, GA: CDC, Www.cdc.gov/nchhstp/healthdisparities/docs/nchhstphealthdisparitiesreport1107.pdf. 2007. Accessed October 17, 2015.

13. CDC. Notes from the field: risk factors for hepatitis $\mathrm{C}$ virus infections among young adults - Massachusetts, 2010. MMWR Morb Mortal Wkly Rep. 2011;60(42):1457-1458. www.cdc.gov/mmwr/pdf/wk/mm6042.pdf. Accessed October 17, 2015.

14. CDC. Notes from the field : hepatitis $\mathrm{C}$ virus infections among young adults--rural Wisconsin, 2010. MMWR Morb Mortal Wkly Rep. 2012;61(19):358. www.cdc.gov/mmwr/pdf/wk/mm6119.pdf. Accessed October 17, 2015. 
15. Suryaprasad AG, White JZ, Xu F, et al. Emerging epidemic of hepatitis C virus infections among young nonurban persons who inject drugs in the United States, 2006-2012. Clin Infect Dis. 2014;59(10):1411-1419. http://dx.doi.org/10.1093/cid/ciu643.

16. Zibbell JE, Iqbal K, Patel RC, et al. Increases in hepatitis $\mathrm{C}$ virus infection related to injection drug use among persons aged $\leq 30$ years - Kentucky, Tennessee, Virginia, and West Virginia, 2006-2012. MMWR Morb Mortal Wkly Rep. 2015;64(17):453-458.

17. Division of Viral Hepatitis. Surveillance for Viral Hepatitis, United States -2013. Atlanta, GA: CDC; www.cdc.gov/hepatitis/statistics/2013surveillance/index.htm. Updated June 25, 2015. Accessed October 19, 2015.

18. Hepatitis C: testing baby boomers saves lives. Center for Disease Control and Prevention website. http://www.cdc.gov/features/vitalsigns/hepatitisc/. Updated May 2013. Accessed June 1, 2015.

19. Moyer VA. Screening for hepatitis C virus infection in adults: U.S. Preventive Services Task Force recommendation statement. Ann Intern Med. 2013;159(5):349-357.

20. Chou R, Cottrell EB, Wasson N, Rahman B, Guise JM. Screening for hepatitis C virus infection in adults: a systematic review for the U.S. Preventive Services Task Force. Ann Intern Med. 2013;158(2):101-108. http://dx.doi.org/10.7326/0003-4819-158-2$201301150-00574$.

21. Armstrong GL, Wasley A, Simard EP, Mcquillan GM, Kuhnert WL, Alter MJ. The prevalence of hepatitis C virus infection in the United States, 1999 through 2002. Ann Intern Med. 2006;144(10):705-714. http://dx.doi.org/10.7326/0003-4819-144-10200605160-00004. 
22. Pollini RA, Banta-green CJ, Cuevas-mota J, Metzner M, Teshale E, Garfein RS.

Problematic use of prescription-type opioids prior to heroin use among young heroin injectors. Subst Abuse Rehabil. 2011;2(1):173-180.

http://dx.doi.org/10.2147/SAR.S24800.

23. McCabe SE, Cranford JA, West BT. Trends in prescription drug abuse and dependence, co-occurrence with other substance use disorders, and treatment utilization: results from two national surveys. Addict Behav. 2008;33(10):1297-1305.

http://dx.doi.org/10.1016/j.addbeh.2008.06.005.

24. Vickerman P, Martin NK, Hickman M. Understanding the trends in HIV and hepatitis C prevalence amongst injecting drug users in different settings--implications for intervention impact. Drug Alcohol Depend. 2012;123(1-3):122-131. http://dx.doi.org/10.1016/j.drugalcdep.2011.10.032.

25. Yaphe S, Bozinoff N, Kyle R, Shivkumar S, Pai NP, Klein M. Incidence of acute hepatitis $\mathrm{C}$ virus infection among men who have sex with men with and without HIV infection: a systematic review. Sex Transm Infect. 2012;88(7):558-564. http://dx.doi.org/10.1136/sextrans-2012-050566.

26. Beyrer C, Baral SD, Van griensven F, et al. Global epidemiology of HIV infection in men who have sex with men. Lancet. 2012;380(9839):367-377. http://dx.doi.org/10.1016/S0140-6736(12)60821-6.

27. Bradshaw D, Matthews G, Danta M. Sexually transmitted hepatitis C infection: the new epidemic in MSM? Curr Opin Infect Dis. 2013;26(1):66-72. http://dx.doi.org/10.1097/QCO.0b013e32835c2120. 
28. Witt MD, Seaberg EC, Darilay A, et al. Incident hepatitis C virus infection in men who have sex with men: a prospective cohort analysis, 1984-2011. Clin Infect Dis. 2013;57(1):77-84. http://dx.doi.org/10.1093/cid/cit197.

29. Buchbinder SP, Katz MH, Hessol NA, Liu J, O'malley PM, Alter MJ. Hepatitis C virus infection in sexually active homosexual men. J Infect. 1994;29(3):263-269. http://dx.doi.org/10.1016/S0163-4453(94)91128-2.

30. Schmidt AJ, Rockstroh JK, Vogel M, et al. Trouble with bleeding: risk factors for acute hepatitis $\mathrm{C}$ among HIV-positive gay men from Germany--a case-control study. PLoS ONE. 2011;6(3):e17781. http://dx.doi.org/10.1371/journal.pone.0017781.

31. Colfax G, Vittinghoff E, Husnik MJ, et al. Substance use and sexual risk: a participantand episode-level analysis among a cohort of men who have sex with men. Am J Epidemiol. 2004;159(10):1002-1012. http://dx.doi.org/10.1093/aje/kwh135.

32. Urbanus AT, Van de laar TJ, Stolte IG, et al. Hepatitis C virus infections among HIVinfected men who have sex with men: an expanding epidemic. AIDS. 2009;23(12):F1-7. http://dx.doi.org/10.1097/QAD.0b013e32832e5631.

33. Holmberg SD, Spradling PR, Moorman AC, Denniston MM. Hepatitis C in the United States. N Engl J Med. 2013;368(20):1859-1861. http://dx.doi.org/10.1056/NEJMp1302973.

34. Galbraith JW. Hepatitis C Virus Screening: An Important Public Health Opportunity for United States Emergency Departments. Ann Emerg Med. 2015. http://dx.doi.org/10.1016/j.annemergmed.2015.08.002. 
35. Turner BJ, Taylor BS, Hanson J, et al. High priority for hepatitis C screening in safety net hospitals: Results from a prospective cohort of 4582 hospitalized baby boomers. Hepatology. 2015;62(5):1388-1395. http://dx.doi.org/10.1002/hep.28018.

36. AASLD/IDSA/IAS-USA. Recommendations for testing, managing, and treating hepatitis C. www.hcvguidelines.org. Accessed on October 19, 2015.

37. University of New Mexico School of Medicine. Project ECHO website. Hepatitis C Community. http://echo.unm.edu/nm-teleecho-clinics/hepatitis-c-community-clinic/. Accessed June 1, 2015.

38. Everhart JE. Viral Hepatitis. In: The burden of digestive diseases in the United States. U.S. DHHS, Public Health Service, NIH, National Institute of Diabetes and Digestive and Kidney Diseases. Washington DC: U.S. Government Printing Office; 2008:13-23.

39. El khoury AC, Klimack WK, Wallace C, Razavi H. Economic burden of hepatitis Cassociated diseases in the United States. J Viral Hepat. 2012;19(3):153-160. http://dx.doi.org/10.1111/j.1365-2893.2011.01563.x.

40. Myers RP, Krajden M, Bilodeau M, et al. Burden of disease and cost of chronic hepatitis C infection in Canada. Can J Gastroenterol Hepatol. 2014;28(5):243-250.

41. Saag MS. Editorial commentary: getting smart in how we pay for HCV drugs: KAOS vs CONTROL. Clin Infect Dis. 2015;61(2):169-170. http://dx.doi.org/10.1093/cid/civ221.

42. Barua S, Greenwald R, Grebely J, Dore GJ, Swan T, Taylor LE. Restrictions for Medicaid Reimbursement of Sofosbuvir for the Treatment of Hepatitis C Virus Infection in the United States. Ann Intern Med. 2015;163(3):215-223. http://dx.doi.org/10.7326/M15-0406. 
43. Canary LA, Klevens RM, Holmberg SD. Limited Access to New Hepatitis C Virus Treatment Under State Medicaid Programs. Ann Intern Med. 2015;163(3):226-228. http://dx.doi.org/10.7326/M15-0320.

44. AASLD/IDSA/IAS-USA. Overview of Cost, Reimbursement, and Cost-Effectiveness Considerations for Hepatitis C Treatment Regimens. Recommendations for testing, managing, and treating hepatitis C. www.hcvguidelines.org/full-report/overview-costreimbursement-and-cost-effectiveness-considerations-hepatitis-c-treatment. Accessed on October 19, 2015.

45. Imran M, Manzoor S, Khattak NM, et al. Current and future therapies for hepatitis C virus infection: from viral proteins to host targets. Arch Virol. 2014;159(5):831-846. http://dx.doi.org/10.1007/s00705-013-1803-7.

46. Liang TJ, Ghany MG. Current and future therapies for hepatitis C virus infection. $N$ Engl J Med. 2013;368(20):1907-1917. http://dx.doi.org/10.1056/NEJMra1213651.

47. AASLD/IDSA/IAS-USA. Initial Treatment of HCV Infection. Recommendations for testing, managing, and treating hepatitis C. www.hcvguidelines.org/full-report/overviewcost-reimbursement-and-cost-effectiveness-considerations-hepatitis-c-treatment. Accessed on October 19, 2015.

48. Chhatwal J, Kanwal F, Roberts MS, Dunn MA. Cost-effectiveness and budget impact of hepatitis $\mathrm{C}$ virus treatment with sofosbuvir and ledipasvir in the United States. Ann Intern Med. 2015;162(6):397-406. http://dx.doi.org/10.7326/M14-1336.

49. Leidner AJ, Chesson HW, Xu F, Ward JW, Spradling PR, Holmberg SD. Costeffectiveness of hepatitis $\mathrm{C}$ treatment for patients in early stages of liver disease. Hepatology. 2015;61(6):1860-1869. http://dx.doi.org/10.1002/hep.27736. 
50. Linas BP, Barter DM, Morgan JR, et al. The cost-effectiveness of sofosbuvir-based regimens for treatment of hepatitis $\mathrm{C}$ virus genotype 2 or 3 infection. Ann Intern Med. 2015;162(9):619-629. http://dx.doi.org/10.7326/M14-1313.

51. Najafzadeh M, Andersson K, Shrank WH, et al. Cost-effectiveness of novel regimens for the treatment of hepatitis C virus. Ann Intern Med. 2015;162(6):407-419. http://dx.doi.org/10.7326/M14-1152.

52. Rein DB, Wittenborn JS, Smith BD, Liffmann DK, Ward JW. The cost-effectiveness, health benefits, and financial costs of new antiviral treatments for hepatitis $\mathrm{C}$ virus. Clin Infect Dis. 2015;61(2):157-168. http://dx.doi.org/10.1093/cid/civ220.

53. Younossi ZM, Park H, Saab S, Ahmed A, Dieterich D, Gordon SC. Cost-effectiveness of all-oral ledipasvir/sofosbuvir regimens in patients with chronic hepatitis $\mathrm{C}$ virus genotype 1 infection. Aliment Pharmacol Ther. 2015;41(6):544-563. http://dx.doi.org/10.1111/apt.13081.

54. Jezequel C, Bardou-Jacquet E, Desille Y et al. Survival of patients infected by chronic hepatitis $\mathrm{C}$ and F0F1 fibrosis at baseline after a 15 year follow-up. 50th Annual Meeting of the European Association for the Study of the Liver (EASL). April 22-26, 2015; S589; Vienna, Austria.

55. Zahnd C, Salazar-Vizcaya LP, Dufour JF et al. Impact of deferring HCV treatment on liver-related events in HIV+ patients. Conference on Retroviruses and Opportunistic Infections (CROI) 2015. February 23-26, 2015; Seattle, WA

56. The Joint Commission. Performance Measurement for Hospitals Website. Facts about ORYX® for Hospitals (National Hospital Quality Measures). 
www.jointcommission.org/accreditation/performance_measurementoryx.aspx. Accessed October 17, 2015.

57. National Center for Quality Assurance. HEDIS \& Performance Measurement website. www.ncqa.org/HEDISQualityMeasurement.aspx. Accessed October 17, 2015.

58. Center for Medicare and Medicaid Services. Physician Quality Reporting System website. www.ncqa.org/HEDISQualityMeasurement.aspx. Accessed October 17, 2015.

59. Williams SC, Schmaltz SP, Morton DJ, Koss RG, Loeb JM. Quality of care in U.S. hospitals as reflected by standardized measures, 2002-2004. N Engl J Med. 2005;353(3):255-264. http://dx.doi.org/10.1056/NEJMsa043778.

60. Werner RM, Bradlow ET. Relationship between Medicare's hospital compare performance measures and mortality rates. JAMA. 2006;296(22):2694-2702. http://dx.doi.org/10.1001/jama.296.22.2694.

61. Peterson ED, Roe MT, Mulgund J, et al. Association between hospital process performance and outcomes among patients with acute coronary syndromes. JAMA. 2006;295(16):1912-1920. http://dx.doi.org/10.1001/jama.295.16.1912.

62. American Gastroenterological Association. The physician quality reporting system (PQRS) and Value-Based Payment Modifier. North Chicago, IL www.gastro.org/practice-management/quality/4001683302_PQRS_and_VBM_for_HCV_Flashcard.pdf. May 2015. Accessed June 1, 2015. 63. Office of HIV/AIDS and Infectious Disease Policy. Action Plan for Prevention, Care and Treatment of Viral Hepatitis. Washington DC. www.aids.gov/pdf/viral-hepatitis-actionplan.pdf. Accessed June 1, 2015. 
64. American Liver Foundation. Hepatitis Diagnosis, Treatment and Support website. http://hepc.liverfoundation.org/diagnosis/who-should-get-tested/. Accessed June 1, 2015.

65. Institute of the Medicine of the National Academies. Colvin, HM, Mitchell, AE. Hepatitis and Liver Cancer: A National Strategy for the Prevention and Control of Viral Hepatitis Infections. Washington DC. The National Academies Press; 2010.

66. Canadian Liver Foundation. Hepatitis C website. www.liver.ca/liverdisease/types/viral_hepatitis/Hepatitis_C.aspx\#2. Accessed on June 1, 2015. 
Table 1. Recommendations on HCV Screening, Transfer of Care and Treatment by Professional Organization

\begin{tabular}{|c|c|}
\hline Agency or organization & $\begin{array}{l}\text { Recommendation (Screening, transfer of care, } \\
\text { treatment), evidence grading, }{ }^{\mathrm{a}} \text { year of } \\
\text { recommendation }\end{array}$ \\
\hline $\begin{array}{l}\text { U.S. Preventive Services Task } \\
\text { Force (USPSTF) } \\
\text { (U,20 }^{19}\end{array}$ & $\begin{array}{l}\text { Screening: 1. Screening for hepatitis C virus (HCV) } \\
\text { infection in persons at high risk for infection (B } \\
\text { recommendation, 2013). } 2 \text {. Offering one-time screening } \\
\text { for HCV infection to adults born between } 1945 \text { and } 1965 \\
\text { (B recommendation, 2013). }\end{array}$ \\
\hline $\mathrm{CDC}^{18}$ & $\begin{array}{l}\text { Screening: One-time testing without prior ascertainment } \\
\text { of HCV risk for persons born during } 1945-1965 \text { (strong } \\
\text { recommendation, moderate quality of evidence, 2012). } \\
\text { Transfer of care: Early detection and treatment of } \\
\text { asymptomatic individuals. Treatment decisions should be } \\
\text { made by the patient and provider after several factors are } \\
\text { considered, including stage of disease, hepatitis C } \\
\text { genotype, comorbidities, therapy-related adverse events, } \\
\text { and benefits of treatment. }\end{array}$ \\
\hline $\begin{array}{l}\text { American Liver Foundation } \\
(\mathrm{ALF})^{64}\end{array}$ & $\begin{array}{l}\text { Screening: HCV testing at least once for persons born } \\
\text { between } 1945 \text { and } 1965 . \\
\text { Rating: Class I, Level B (2014) } \\
\text { Other persons should be screened for risk factors for HCV } \\
\text { infection, and one-time testing should be performed for all } \\
\text { persons with behaviors, exposures, and conditions } \\
\text { associated with an increased risk of HCV infection } \\
\text { Rating: Class I, Level B (2014) }\end{array}$ \\
\hline $\mathrm{IOM}^{65}$ & $\begin{array}{l}\text { Screening: Risk-factor screening for hepatitis C should be } \\
\text { included as a core component of preventive care (2010) }\end{array}$ \\
\hline Canadian Liver Foundation ${ }^{66}$ & $\begin{array}{l}\text { Screening: All adults born between } 1945 \text { and } 1975 \\
\text { undergo a test for hepatitis C. (2014) }\end{array}$ \\
\hline $\begin{array}{l}\text { American Association for the } \\
\text { Study of Liver Diseases } \\
\text { (AASLD)/Infectious Disease } \\
\text { Society of America } \\
\text { (IDSA)/International Antiviral } \\
\text { Society-USA(IAS) }\end{array}$ & $\begin{array}{l}\text { Screening (2014): } \\
\text { 1. HCV testing at least once for persons born between } \\
1945 \text { and } 1965 \text { without ascertainment of risk. (Rating: } \\
\text { Class I, level B) } \\
\text { 2. Other persons should be screened for risk factors for } \\
\text { HCV infection, and one-time testing should be performed } \\
\text { for all persons with behaviors, exposures, and conditions } \\
\text { associated with an increased risk of HCV infection. } \\
\text { (Rating: Class I, level B) } \\
\text { 3. Annual HCV testing for persons who inject drugs and } \\
\text { for HIV seropositive men who have unprotected sex with } \\
\text { men. Periodic testing should be offered to other persons } \\
\text { with ongoing risk factors for exposure to HCV. } \\
\text { (Rating: Class IIA, Level C) } \\
\text { Transfer of care (2014): }\end{array}$ \\
\hline
\end{tabular}




\begin{tabular}{l|l}
\hline & 1. Evaluation by a practitioner who is prepared to provide \\
comprehensive management, including consideration of \\
antiviral therapy, is recommended for all persons with \\
current (active) HCV infection.(Rating: Class IIa, level C) \\
2. Persons with current (active) HCV infection should \\
receive education and interventions aimed at reducing \\
progression of liver disease and preventing transmission \\
of HCV. (Rating: Class IIa, Level B) \\
Treatment (2015): \\
1. Treatment for all patients with chronic HCV infection is \\
recommended, except those with short life \\
expectancies that cannot be remediated by treating HCV, \\
by transplantation, or by other directed therapy. \\
(Class I, Level A) \\
2. Pretreatment assessment of a patient's understanding of \\
treatment goals and provision of education on adherence \\
and follow-up are essential. A well-established therapeutic \\
relationship between practitioner and patient remains \\
crucial for optimal outcomes with new direct-acting \\
antiviral (DAA) therapies.
\end{tabular}

${ }^{a}$ See citations for how each agency or organization defined evidence grade. 